Науковий вісник НлТУ України Scientific Bulletin of UNFU http://nv.nltu.edu.ua

https://doi.org/10.15421/40290716

Article received $27.08 .2019 \mathrm{p}$.

Article accepted 26.09.2019 p.

удк 712.3:635.9(477.43/44)
ISSN 1994-7836 (print)

ISSN 2519-2477 (online)

$@ \bowtie$ Correspondence author

H. V. Pantsyreva

apantsyreva@ukr.net

Г. В. Панцирева

Вінницький національний аграрний університет, м. Вінниия, Украӥна

\title{
НАСІННЄВА ПРОДУКТИВНІСТЬ ДЕКОРАТИВНИХ ВИДІВ РОДУ LUPINUS В УМОВАХ ПОДІЛЛЯ
}

\begin{abstract}
Наведено результати насіннєвої продуктивності квітниково-декоративних рослин, що належать до представників роду Lupinus L. в умовах Поділля. Проаналізовано видовий склад роду Lupinus та визначено перспективність їх використання для озеленення різних об'єктів зони Поділля. 3 метою диференціації рослин, відповідно до сфери їх можливого використання, наведено експериментальні дослідження найбільш перспективних представників цього роду, в яких встановлено, що онтогенез усіх досліджуваних сортів/гібридів завершується у цих умовах повноцінним плодоношенням, період якого в більшості видів триває від 43 до 82 днів. Враховуючи тривалість життя окремої квітки, дозрівання кожного плоду в цих рослин займає значний проміжок часу в їх онтогенезі. Дослідженням встановлено, що всі досліджувані види викликають інтерес як потенційно цінні об'єкти для збагачення асортименту вітчизняних декоративних рослин та є перспективними для поліпшення стану парків, скверів, садків зони Поділля. Також дослідженнями визначено природні можливості представників роду Lupinus, пластичність до зміни їх життєвої форми, високу якість за сукупністю ознак, що визначають їхню декоративність і характеризують досліджувані рослини, як джерело для інтродукції і збагачення асортименту декоративних культур в Україні. Отже, вивчення питання щодо насіннєвої продуктивності роду Lupinus для озеленення дасть змогу значно розширити асортимент декоративно цінних рослин та збагатити культивовану флору зони Поділля та України загалом.
\end{abstract}

Ключові слова: насіннєва продуктивність; люпин; коефіцієнт продуктивності; природний ареал; онтогенез.

Вступ. Однією з найважливіших проблем сучасності $\epsilon$ вивчення питання щодо збереження навколишнього середовища і створення здорових і сприятливих умов для життя і праці людини. Значні порушення в біосфері Землі, що призводять до розбалансування екологічної рівноваги в масштабі цілих регіонів, потребують невідкладного розроблення теоретичних і практичних основ зеленого благоустрою населених пунктів та місць рекреації. Оптимізація середовища за допомогою квітководекоративних рослин - найбільш надійний і доцільний шлях до створення здорових і сприятливих умов для життя і праці людини (Mazur et al., 2019).

В умовах сьогодення у декоративному садівництві посилюється тенденція використання нових багаторічних рослин з тривалим періодом цвітіння та декоративного ефекту. Тому представники роду Lupinus становлять вагомий інтерес. Досліджувані види характеризуються витонченістю і вишуканістю, які втрачені багатьма садовими декоративними формами і гібридами, різняться за висотою, габітусом куща, забарвленням квітки. До умов зростання види роду невибагливі, тому що в природних умовах вони ростуть на бідних, переважно піщаних грунтах (Pantsyreva, 2018).

Широке застосування квітково-декоративних видів роду Lupinus у сучасному озелененні в умовах Поділля України стримує недостатня вивченість їхніх біологічних та декоративних особливостей і відсутність науко- во обгрунтованих рекомендацій з вирощування та розмноження видів в умовах культури. 3 огляду на це, питання щодо насіннєвої продуктивності $є$ актуальним для розширення асортименту квітково-декоративних рослин в озелененні і для збереження генофонду видів природної флори (Ishchuk et al., 2014).

Аналіз останніх досліджень і публікацій. Проаналізувавши літературні джерела, встановлено, що рід $L u$ pinus налічує близько 200 видів, що зростають у Північній Америці та Середземномор'ї. Це - багаторічні кореневищні трав'янисті рослини, рідше напівчагарники (Pantsyreva, 2018; Landshaftnaia studiia "Dizain Plius", 2019).

3 багаторічних видів у культурі частіше трапляються люпин деревоподібний (L. arboreus Sims.) - багаторічна рослина, 1,5 м заввишки, 3 білими і жовтими кольорами, квітне в липні-серпні. 31826 р. у культурі люпин багатолистий (L. polyphyllus Lindl.) 3 численними садовими формами і сортами гібридного походження, з квітками як однотонними, так і двокольоровими: Abendglut, Albus, Apricot, Carmineus, Neue Spielarten, Prinzess Juliana, Roseus, Rubinkonig (Landshaftnaia studiia "Dizain Plius", 2019).

Тривалий час селекцією люпину займався англійський селекціонер Джордж Рассел. В Україні значного поширення набули одноколірні сортопопуляції, виділені $з$ гібридів Рассела: Бург Фройлен, Кронлойхтер,

Інформація про авторів:

Панцирева Ганна Віталіївна, канд. с.-г. наук, ст. викладач, кафедра садово-паркового господарства, садівництва та виноградарства. Email: apantsyreva@ukr.net; https://orcid.org/0000-0002-0539-5211

Цитування за ДСту: Панцирева Г. В. Насіннєва продуктивність декоративних видів роду Lupinus в умовах Поділля. Науковий вісник НЛтУ України. 2019, т. 29, № 7. С. 80-83.

Citation APA: Pantsyreva, H. V. (2019). Seed Productivity of Decorative Lupinus Species in the Conditions of Podillya. Scientific Bulletin of UNFU, 29(7), 80-83. https://doi.org/10.15421/40290716 
Шлоссфрау, Майн Шлосс, Еделькбане, Кастеллян. Окрім одноколірних, сьогодні існують унікальні різноколірні сортопопуляції з широким спектром тонів і відтінків від білого до фіолетового: Абенглют, Сплендід. Серед новинок дуже ефектна низькоросла сортопопуляція Мінарет. Люпин Лулу - найскороспіліша суміш сортів серед багаторічного люпину (Ishchuk et al., 2014; Atkins, 2002).

Люпин висаджують в одиночних і групових насадженнях 3 іншими багаторічниками в міксбордерах, групами на газоні. Ефектні в букетах, але стоять недовго. Люпини - рослини другого ряду. Добре поєднуються в мішаних насадженнях із хостами, півниками, ромашками, лілеями, дельфініями, астильбами та ін. (Ishchuk et al., 2014; Mazur, Prokopchuk \& Pantsyreva, 2018; Kormilitcyn, 1966a; Entciklopediia dekorativnykh sadovykh rastenii, 2019).

Враховуючи високі декоративні властивості цих видів та широкі можливості їх застосування, ці рослини становлять значний інтерес для садівництва нашої України та для поповнення асортименту квітниково-декоративних культур.

Метою $i$ завданням є дослідження насіннєвої продуктивності та біоморфологічних особливостей сортів/гібридів декоративно-цінних представників роду $\mathrm{Lu}$ pinus та визначення перспективності їх вирощування в умовах зони Поділля.

Матеріал та методи дослідження. Дослідження проводили впродовж 2018-2019 рр. на базі експозиційної ділянки кафедри лісового, садово-паркового господарства, садівництва та виноградарства факультету агрономії та лісівництва Вінницького національного аграрного університету. Грунтово-кліматичні умови зони дослідження сприятливі для вирощування перерахованих видів роду Lupinus.

Результати дослідження та їх обговорення. 3 безлічі видів представників роду Lupinus (за класифікацією різних авторів від декількох десятків до декількох сотень) в більшості країн світу, зокрема й в Україні, культивують тільки чотири: люпин вузьколистий (L. angustifolius L.), люпин жовтий (L. luteus L.), люпин білий (L. albus L.), люпин мінливий (L. mutabilis L.). Створені малоалкалоїдні форми багаторічного люпину багатолистого (L. polyphyllus Lindl.) мають попит, однак ще не створено насіннєвого фонду. На підставі цього виду отримано багато сортів (переважно закордонної селекції), які використовують як декоративну культуру.
На відміну від інших культур, багато видів люпину введені в культуру зовсім недавно: вузьколистий і жовтий - в середині XIX ст., інші види - у XX ст. Тільки два види люпину - мінливий і білий - давні культурні рослини, культивуються протягом тисячоліть. Так, сучасні культурні форми цих видів за морфологічними особливостями, забарвленням і розміром відрізняються від стародавніх представників (Kormilitcyn, 1966b). Культивовані донедавна види люпину також відрізняються від зростаючих у дикій природі за габітусом рослини, абортивністю квіток і бобів, розміром та якістю насіння, стійкістю до біотичних і абіотичних чинників (Sowling, 1994).

Враховуючи те, що найбільше видове різноманіття 3 переважною кількістю багаторічних видів люпину зосереджено в Новому Світі й невелика кількість - у Середземномор'ї (Старий Світ), серед дикорослих видів роду Lupinus чимало перспективних форм, придатних для введення в культуру в Україні. Агрокліматичні умови нашої країни, а також успішна інтродукція представників диких видів люпину у віддалені від центрів їх походження регіони, є підставою для введення їх у зону Поділля (Atkins, 2002).

Усі види люпину на цей материк завезли перші поселенці з Америки. Наприкінці минулого століття, поряд 3 традиційними у світі видами люпину (вузьколистим, білим, жовтим і мінливим), в Австралії селекцією були створені нові види 3 декоративними властивостями L. cosentinii Guss., L. athlanticus Gladst. і L. pilosus Murr, які стали невід'ємною частиною австралійських наукових досліджень.

3 незначного досвіду вирощування декоративних рослин цього роду, переважна більшість із них в умовах країн Європи, а також США та Канади здатні добре розвиватись, переносити холодний період року, цвісти та плодоносити. Проте сьогодні залишається недостатньо вивченим питання щодо характеристики зазначених вище видів.

Вивчення біоморфологічних особливостей окремих видів чи їх культиварів має важливе теоретичне та практичне значення для сучасного декоративного садівництва. Встановлено, що в умовах Поділля люпин багатолистий та люпин багаторічний за життєвою формою - трав'янисті полікарпіки, геофіти; за екоморфою геліофіти, але легко проявляються як геліосциофіти; за гідроморфою - мезофіти; за феноритмотипом належать до групи літньо-осінньо-зелених рослин (табл. 1).

Табл. 1. Біоморфологічні особливості, строки цвітіння та забарвлення квітки декоративних видів роду Lupinus L.

\begin{tabular}{|c|c|c|c|c|}
\hline Назва сорту/гібриду & Життєва форма & Тип вегетації & Термін цвітіння & Забарвлення квітки \\
\hline \multicolumn{5}{|c|}{ Люпин багатолистий (L. Polyphyllus Lindl.) } \\
\hline Лулу-рассел & \multirow[t]{2}{*}{ багаторічник } & літньо-зелений & червень-липень & світло-рожеве \\
\hline Мінарет & & літньо-осінньо-зелений & серпень-вересень & біле, жовте, рожеве, голубе \\
\hline \multicolumn{5}{|c|}{ Люпин багаторічний (L. perennis L.) } \\
\hline Альбус & \multirow{2}{*}{ багаторічник } & \multirow{2}{*}{ літньо-осінньо-зелений } & липень-серпень & біло-рожеве \\
\hline Феєрверк & & & травень-липень & фіолетове, рожеве \\
\hline
\end{tabular}

Спостерігаючи за ростом і розвитком декоративноцінних видів люпину, досліджено, що сорти та гібриди призначені для прикраси квітника, благоустрою ділянок завдяки створенню сучасних садових композицій. На відміну від кормових сортів вітчизняної селекції, досліджувані рослини виглядають більш яскраво та ефектно.

За результатами досліджень навели основні морфометричні показники (висота рослин, забарвлення квітки та терміни цвітіння) найбільш перспективних декоративно-цінних представників роду Lupinus (табл. 2).
Табл. 2. Морфометричні показники основних декоративно-цінних представників роду Lupinus

\begin{tabular}{|c|c|c|}
\hline \multirow{2}{*}{ Назва сорту/гібриду } & \multicolumn{2}{|c|}{ Розмір рослин, см } \\
\cline { 2 - 3 } & висота & ширина \\
\hline Люпин багатолистий (L. Polyphyllus Lindl.) \\
\hline Лулу-рассел & 50 & $20-25$ \\
\hline Мінарет & 50 & $30-35$ \\
\hline \multicolumn{2}{|c|}{ Люпин багаторічний (L. perennis L.) } \\
\hline Альбус & 120 & $40-50$ \\
\hline Фесрверк & 150 & $50-60$ \\
\hline
\end{tabular}


Таким чином, природні можливості представників роду Lupinus L., пластичність до зміни їх життєвої форми, висока якість за сукупністю ознак, що визначають їхню декоративність, характеризують ці рослини як джерело для інтродукції і збагачення асортименту декоративних культур в Україні.

У процесі досліджень встановили, що онтогенез досліджуваних видів завершується у цих умовах повноцінним плодоношенням. Показники, за якими характеризують успішність насіннєвого розмноження рослин, у досліджуваних видів люпину змінюються у широкому діапазоні. При цьому найвищий показник зафіксували у люпину багаторічного сорту Феєрверк (табл. 3).

Табл. 3. Показники насіннєвої продуктивності декоративних видів роду Lupinus L.

\begin{tabular}{|c|c|c|c|}
\hline $\begin{array}{c}\text { Назва } \\
\text { срту/гіб- } \\
\text { риду }\end{array}$ & $\begin{array}{c}\text { Потенційна на- } \\
\text { сіннєва про- } \\
\text { дуктивність, } \\
\text { шт./плід }\end{array}$ & $\begin{array}{c}\text { Фактична насіннєва } \\
\text { продуктивність, } \\
\text { шт./плід }\end{array}$ & $\begin{array}{c}\text { Коефіцієнт } \\
\text { продуктив- } \\
\text { ності, \% }\end{array}$ \\
\hline \multicolumn{3}{|c|}{ Люпин багатолистий (L. Polyphyllus Lindl.) } \\
\hline $\begin{array}{c}\text { Лулу-рас- } \\
\text { сел }\end{array}$ & 60 & 49 & 81,6 \\
\hline Мінарет & 74 & 62 & 83,7 \\
\hline \multicolumn{4}{|c|}{ Люпин багаторічний (L. perennis L.) } \\
\hline Альбус & 96 & 62 & 64,5 \\
\hline Феєрверк & 130 & 118 & 90,7 \\
\hline
\end{tabular}

За комплексом показників, 3 урахуванням якості цього насіння (схожості та енергії проростання), більшість досліджуваних видів характеризуються високим рівнем насіннєвої продуктивності.

За даними проведених досліджень встановлено, що показники продуктивності свідчать про сприятливість умов зони Поділля для насінництва більшості сортів/гібридів, які були піддані тестуванню. Подальше вивчення посівних якостей насіння, зібраного 3 досліджуваних рослин, по-різному реагує на світловий режим пророщування (табл. 4).

Табл. 4. Посівні якості насіння декоративних видів роду Lupinus L.

\begin{tabular}{|c|c|c|c|c|c|}
\hline \multirow{2}{*}{$\begin{array}{l}\text { Назва сор- } \\
\text { ту/гібриду }\end{array}$} & \multicolumn{2}{|c|}{$\begin{array}{c}\text { Енергія } \\
\text { проростання, \% }\end{array}$} & \multicolumn{2}{|c|}{ Схожість, \% } & \multirow{2}{*}{$\begin{array}{c}\text { Воло- } \\
\text { гість, } \\
\%\end{array}$} \\
\hline & на світлі & у темряві & на світ & у темряві & \\
\hline \multicolumn{6}{|c|}{ Люпин багатолистий (L. Polyphyllus Lindl.) } \\
\hline оассел & 32 & 24 & 42 & 38 & 7 \\
\hline & 53 & 49 & 80 & 72 & 8 \\
\hline \multicolumn{6}{|c|}{ Люпин багаторічний (L. perennis L.) } \\
\hline Іьбус & 72 & 68 & 84 & 80 & 9 \\
\hline Феєрверк & 89 & 80 & 95 & 92 & 6 \\
\hline
\end{tabular}

Так, на світлі та в темряві найвищий показник енергії проростання зафіксували на ділянках люпину багатолистого сорту Феєрверк (відповідно 89 та $80 \%$ ) та схожість насіння (відповідно 95 та $92 \%$ ) за вологості насіння $6 \%$. Дещо нижчі показники зафіксували на рослинах люпину багатолистого сортів Лулу-рассел та Мінарет.

Успішність інтродукції підтверджують також дані щодо здатності досліджуваних видів до вегетативного розмноження. Так, за період проведених досліджень (2018-2019 pр.) у таких видів, як L. Polyphyllus Lindl. та $L$. perennis L., спостерігали інтенсивний розвиток стрижневого кореня та бічних кореневищ. Штучне розмноження здійснювали способом поділу цих кореневищ, що можна успішно проводити весною, або шляхом укорінення стеблових живців. Це забезпечує додаткові можливості внаслідок обмеженого насіннєвого розмноження і є важливим способом збереження цінних компонентів спадковості, що доцільно використати під час розроблення селекційних програм та для оптимізації процесу вирощування в зеленому будівництві.

Вегетативне розмноження вигідно відрізняється від насінного тим, що воно забезпечує повну передачу господарських і біологічних батьківських ознак нащадкам, а вирощування посадкового матеріалу не залежить від плодоношення і дозрівання насіння.

Серед різних способів вегетативного розмноження найбільшого поширення у виробництві набуло зелене живцювання, особливості якого висвітлені у роботах таких авторів, як: Р. Х. Турецька (1949), М. Т. Тарасенко (1967), М. К. Вєхов, М. П. Ільїн (1934), W. L. Doran (1941), J. S. Wells (1955), P. Rowe-Dutton (1959).

На нашу думку, успіх зеленого живцювання для різних видів люпину значно залежить від термінів живцювання, коли живці мають найбільшу здатність до регенерації (табл. 5).

Табл. 5. Вкорінення зелених живців залежно від термінів живцювання у декоративних видів роду Lupinus L., \%

\begin{tabular}{|c|c|c|c|}
\hline \multirow{2}{*}{$\begin{array}{c}\text { Назва сорту / } \\
\text { гібриду }\end{array}$} & $\begin{array}{c}\text { ДІ декада } \\
\text { травня }\end{array}$ & $\begin{array}{c}\text { II декада } \\
\text { червня }\end{array}$ & $\begin{array}{c}\text { I декада } \\
\text { липня }\end{array}$ \\
\hline \multicolumn{4}{|c|}{ Люпин багатолистий (L. Polyphyllus Lindl.) } \\
\hline Лулу-рассел & 86,5 & 69,3 & 42,7 \\
\hline Мінарет & 90,4 & 77,2 & 48,8 \\
\hline \multicolumn{4}{|c|}{ Люпин багаторічний (L. perennis L.) } \\
\hline Альбус & 82,4 & 62,7 & 40,3 \\
\hline Фесрверк & 92,1 & 87,6 & 68,3 \\
\hline
\end{tabular}

Здатність живців до вкорінення зумовлюється регенеративними особливостями рослин. Найвищу здатність до вкорінення відзначили у люпину багаторічного сорту Феєрверк (92,1%), що зумовлено значним періодом росту пагонів у цього виду (Nemchenko, 2001).

3 практичного погляду всі досліджувані види викликають інтерес як потенційно цінні об'єкти для збагачення асортименту декоративних рослин України та є перспективними для поліпшення стану парків, скверів, садків зони Поділля.

Саме збагачення видової різноманітності декоративних культур інтродукованими видами роду Люпину, розширення варіантів простих і комплексних садових композицій з їх участю, більш рівномірне їх розміщення в межах населених пунктів, значно наблизить оформлення населених міст України до рівня кращих світових зразків.

Висновки. Усі види роду Lupinus, що пройшли первинне інтродукційне випробування за комплексом показників, які визначають їхню декоративність та господарсько-біологічні властивості, оцінюються як добре адаптовані до едафокліматичних умов Поділля і рекомендуються як об'єкти для збагачення асортименту рослин для озеленення колекційних та експозиційних фондів. Встановлено, що інтродуковані види роду Lupi$n u s$ L. відзначаються високими показниками насіннєвої продуктивності. Так, схожість насіння декоративних видів люпину на світлі становить 42-95 \%. При цьому найвища енергія проростання насіння відзначається у люпину багаторічного сорту Феєрверк - 89 \%

\section{Перелік використаних джерел}

Atkins, C. A. (2002). Phenotypic diversity among annual Lupins used for crops or having cropping potential. Internat. Conf. on Legumes Genomic and Genetics. Abstracts, 4 p.

Entciklopediia dekorativnykh sadovykh rastenii. (2019). Entciklopediia sadovykh rastenii. Retrieved from: http://flower.onego.ru/. [In Russian]. 
Ishchuk, L. P. (Ed.), Oleshko, O. H., Cherniak, V. M., \& Kozak, L. A. (2014). Kvitnykarstvo. Bila Tserkva, (pp. 56-57). [In Ukrainian].

Kormilitcyn, A. M. (1966a). Nabliudeniia i nauchnaia dokumentatciia $v$ arboretume GNBS. Yalta, 8 p. [In Russian].

Kormilitcyn, A. M. (1966b). Ukazanii po fenologicheskim nabliudeniiam i biometricheskim izmereniiam v arboretume GNBS. Yalta, 16 p. [In Russian].

Landshaftnaia studiia "Dizain Plius". (2019). Landshaftnyi dizain plius. Retrieved from: https://dsplus.in.ual. [In Russian].

Mazur, V. A., Pantsyreva, H. V., Mazur, K. V., \& Monarkh, V. V. (2019). Ecological and biological evaluation of varietal resources Paeonia L. in Ukraine. Acta Biologica Sibirica, 5(1), 141-146. https://doi.org/10.14258/abs.v5.i1.5350
Mazur, V. A., Prokopchuk, V. M., \& Pantsyreva, H. V. (2018). Pervynne introduktsiine otsiniuvannia dekoratyvnykh vydiv rodu Lupinus v umovakh Podillia. Scientific Bulletin of UNFU, 28(7), 40-43. [In Ukrainian].

Nemchenko, E. P. (2001). Mnogoletnie tcvety v sadu. Moscow: Fiton, 273 p. [In Russian].

Pantsyreva, H. V. (2018). Doslidzhennia sortovykh resursiv travianykh vydiv Paeonia L. v Ukraini. Scientific Bulletin of UNFU, 28(8), 74-78. https://doi.org/10.15421/40280815

Sowling, W. A. (1994). Plant breeding for stable agriculture: Presidential Address. Western Australia, (pp. 183-184).

Vinnytsia National Agrarian University, Vinnytsia, Ukraine

\section{SEED PRODUCTIVITY OF DECORATIVE LUPINUS SPECIES IN THE CONDITIONS OF PODILLYA}

The results of seed productivity of flowering and ornamental plants belonging to the representatives of the genus Lupinus L. in Podillya are presented. The analysis of the species composition of the genus Lupinus and the prospects of their use for landscaping different sites of the Podillya region is presented in the article. In order to differentiate the plants according to the scope of their possible use, experimental studies of the most promising representatives of this genus are provided, which show that the ontogeny of all the studied varieties/hybrids is completed under these conditions by full fruiting, the period of which in most species lasts from 43 to 82 days. Given the life span of a single flower, the ripening of each fruit in these plants takes a considerable amount of time in their ontogeny. The research has found that all the species studied are of interest as potentially valuable objects to enrich the range of native ornamental plants and are promising for improving the condition of parks, squares, gardens in the Podillya area. The success of the introduction is also confirmed by the data on the ability of the species under investigation for vegetative reproduction. Thus, during the period of researches (2018-2019) in such species as L. Polyphyllus Lindl and L. perennis L., intensive development of the root and lateral rhizomes was observed. Artificial reproduction was carried out by dividing these rhizomes, which can be successfully carried out in the spring or by rooting cuttings. This provides additional opportunities for limited seed reproduction and is an important way of preserving valuable components of heredity that is appropriate to use in the development of breeding programs and to optimize the process of cultivation in green building. The research has also identified the natural capabilities of representatives of the genus Lupinus, plasticity to change their life form, high quality on the set of characteristics that determine their decorative characterizes the studied plants, as a source for the introduction and enrichment of the range of ornamental crops in Ukraine. Thus, studying the problem of seed productivity of the genus Lupinus for landscaping will greatly expand the range of ornamental plants and enrich the cultivated flora of the Podillya region and Ukraine as a whole.

Keywords: seed productivity; lupine; productivity factor; natural range; ontogeny. 